\title{
Matgorzata Dowlaszewicz
}

https://orcid.org/0000-0002-2512-1381

Chair of Dutch Philology, University of Wrocław

\section{KNIGHTS IN THE MIDDLE DUTCH EPOS KAREL ENDE ELEGAST*}

\begin{abstract}
Karel (Charlemagne), Elegast, and Eggeric are the three main protagonists of the medieval Dutch epos Karel ende Elegast. Each of them is a knight, but represents different characteristics. The Monarch, the Outlaw, and the Traitor share some chivalric values but present contrasts in their behaviour. This article examines these three characters and their relationships to chivalry. It focuses on the image of chivalry in the epos, and not on the historical aspects of knighthood. As it is one of the first publications in Poland on Middle Dutch texts, it also outlines the chivalric literature in the medieval Low Countries.
\end{abstract}

Keywords: Karel ende Elegast, Charlemagne, chivalry, outlaw, knights

\section{I \\ INTRODUCTION}

Medieval Dutch literature is little known amongst Polish researchers, although the efforts of mainly Andrzej Dąbrówka to propagate study of texts from the Low Countries resulted in several publications. ${ }^{1}$ The recent Polish translation of the Dutch epic poem Karel ende Elegast ${ }^{2}$

* I would like to thank Prof. Ludo Jongen (Leiden University, Netherlands) for inspiration and Prof. Geert Claassens (KU Leuven, Belgium) for his comments on an earlier version of this article.

${ }^{1}$ The most important Polish publication by Dąbrówka is Stownik pisarzy niderlandzkiego obszaru kulturowego (Warszawa, 1999), where the medieval part is significant. He has also authored many entries in Polish encyclopaedias and glossaries.

${ }^{2}$ Marcin Polkowski, Dzieje króla Karola i rycerza Elegasta: niderlandzki epos rycerski $z$ XII wieku (Lublin, 2017). The translation was prepared by the students of the University in Lublin and a brief introduction to the historical context of Karel ende 
may give new possibilities for research, and the most recent history of Dutch literature in Polish is a great resource for knowledge on the early Dutch culture and literary production. ${ }^{3}$

As Karel ende Elegast is a very popular study subject (because its short format makes it more accessible than the long epic poems, or owing to its unique content?), publications about it vary from editions and modern Dutch translations ${ }^{4}$ to study of the dissemination of the story. ${ }^{5}$ One of the issues that arises on various occasions - with diverse conclusions being drawn - is that the particular form of the text does not resemble any other epic poetry on Charlemagne. Its uniqueness is sometimes attributed to the original idea of the unknown Dutch author to base his text on the strange plot; other times the contradictory notion is highlighted that in fact it formed part of a reception chain between France and Northern Europe, the source of which has not been found (yet), although it certainly existed in the Middle Ages. ${ }^{6}$

This article focuses on the way the three male characters of the text are presented in relation to the ideals of knighthood. What roles are attributed to all of them? How do they relate to the rules of the chivalric code of conduct? Does their position change in the course of the story, or are they just mere representations of a certain social position? As the concept of knighthood is still being vividly discussed and there are multiple definitions and time frames related to it, a short explanation of how it is understood here is thus necessary.

In this text knighthood is understood as a social class of noble warriors following a chivalric code of conduct and connected via feudal obligations to their lord.

Elegast is presented, mainly based on the edition by Claassens and the latest history of Dutch literature by Oostrom.

${ }^{3}$ Jerzy Koch and Piotr Oczko (eds.), Widzę rzeki szerokie...: z dziejów dawnej literatury niderlandzkiej, i (Poznań, 2018).

${ }^{4}$ See, e.g., Antonius M. Duinhoven and Karel Eykman, Karel ende Elegast (Amsterdam, 1998).

${ }^{5}$ See, e.g., Jacqueline de Ruiter, 'Karl Magnus' Krønike, Karlamagnús Saga and Karel ende Elegast: Genre, Form, Function', in Enk S. Kooper (ed.), The Medieval Chronicle: Proceedings of the 1st International Conference on the Medieval Chronicle (Amsterdam, 1999), 96-102.

${ }^{6}$ Several studies exploring these ideas are presented in the following parts of this paper. 


\section{CHIVALRIC LITERATURE IN THE LOW COUNTRIES}

The beginnings of the vernacular Dutch literature, as is the case with most European literature, remain shrouded in a great deal of presumptions and speculations, inconsistencies, and discrepancies. Some researchers postulate that vernacular literature as such arose the moment the first story was told in the regional language; others suggest that it was not until the first word or the first sentence had been written down; yet others claim that the Dutch literature did not begin before the first complete literary text had been registered in writing. ${ }^{7}$ The latter theory gives rise to some doubts. For the sake of this paper we shall accept that the oldest known fragments of Dutch come from the sixth century, ${ }^{8}$ and the first text is the paraphrase of the Song of Songs by Williram von Ebersberg from the eleventh century. ${ }^{9}$ The history of Dutch secular literature starts with the poetry of Hendrik van Veldeke and his translation of the Old French Roman d'Eneas, ${ }^{10}$ being at the same time the first example of chivalric literature in the Low Countries.

The Dutch chivalric literature is mostly based on French models, where besides the heroic values and the feudal structure an important part is played by God and religion. This close connection to the French sources was emphasized in the oft-repeated and proven hypotheses of Pentti Tilvis. He argued that the German translations of French epic texts often originated from the intermediary Flemish translations and adaptations. ${ }^{11}$ The low countries' geographical location between the

${ }^{7}$ Where history of Dutch literature presented by Gerard P.M. Knuvelder in his Handboek tot de geschiedenis der Nederlandse letterkunde, i (Den Bosch, 1978) starts with the poetry of Veldeke in the twelfth century, Frits van Oostrom traces the beginnings of Dutch literature in Theo Hermans (ed.), A Literary History of the Low Countries (Rochester and New York, 2009) in the eighth century and the stories told by the blind Frisian poet Bernlef.

${ }^{8}$ Glosses of Malberg in a form of Old Dutch, which accompany the Frankish Lex Salica compiled around the year 500 by Clovis.

${ }^{9}$ Willy Sanders, Der Leidener Willeram. Untersuchungen zu Handschrift, Text und Sprachform (München, 1974) based on the manuscript written around 1100 for the abbey Egmond (Leiden UB, BPL, 130).

${ }^{10}$ Heinrich von Veldeke, Eneasroman. Die Berliner Bilderhandschrift mit Übersetzung und Kommentar, ed. Hans Fromm (Frankfurt a. Main, 1992).

${ }^{11}$ See Pentti Tilvis, 'Mittelniederländisches im Prosa-Lancelot I', Neuphilologische Mitteilungen, lii, 4 (1951), 195-205; and Pentti Tilvis, 'Über die unmittelbaren 
Romanic and Germanic regions seems to be the simplest (although not the only) argument for the important position of French literature in the Low Countries, and Old and Middle Dutch translations could have played a role in the reception of the French epic poetry to the east of the Rhine as well. The dependency on French literature is also seen as one of the reasons why the indigenous Dutch courtly poetry developed so late and functioned within the borders of the (today's) Netherlands until the late thirteen century in its original form, without the need of translation. ${ }^{12}$ This situation changed in the thirteenth century, and both love poetry inspired by the French texts and the translations of short forms and chivalric epic poetry appeared, sometimes in multiple Dutch translations of such works as Perceval of Chrétien de Troyes (Perchevael), and Lancelot en prose, or Fergus (Ferguut). New texts, sometimes based on several different stories, also appeared, such as Roman van Walewein (about Gawain questing for a flying chessboard) or Moriaen (about a black knight in search of his father). ${ }^{13}$

The above examples may give the impression that the Dutch stories of knights were limited to the Arthurian literature, but nothing could be further from the truth. There's also the beautiful translation of Floire et Blancheflor (Floris ende Blancefloer) by Diederik van Assenede, ${ }^{14}$

Vorlagen von Hartmanns "Erec" und "Iwein", Ulrichs "Lanzelet" und Wolframs "Parzival", Neuphilologische Mitteilungen, lx, 1 (1959), 29-65; and the more recent references to the arguments of Tilvis, eg. Markku Kantola, Studien zur Reimsprache des Lanzelet Ulrichs von Zazikhoven: ein Beitrag zur Vorlagenfrage (Turun, 1982), 35; or Thordis Hennings, Altfranzösischer und mittelhochdeutscher Prosa-Lancelot (Winter, 2001), 4.

12 Theo Hermans (ed.), A Literary History of the Low Countries (Rochester and New York, 2009), 15.

${ }^{13}$ Three of them (Perchevael, Lancelot en prose, and Moriaen) can be found in the Hague Lancelot Compilation, edited by Willem J.A. Jonckbloet, Roman van Lancelot (XIIIe eeuw). Naar het (eenig-bekende) Handschrift der Koninklijke Bibliotheek, op gezag van het Gouvernement uitgegeven (The Hague, 1846-9); the manuscript of Ferguut from Leiden University Library MS Ltk 191, edited by Willem Kuiper, Die Riddere metten Witten Scilde. Oorsprong, overlevering en auteurschap van de Middelnederlandse 'Ferguut', gevolgd door een diplomatische editie (Amsterdam, 1989); and the complete manuscript of Roman van Walewein in Leiden University Library MS 195, edited: Penninc \& Pieter Vostaert, De jeeste van Walewein en het schaakbord, ed. G.A. van Es (Zwolle, 1957).

${ }^{14}$ Diederic van Assenede, Floris en Blancefloer. Vertaling en toelichting, Ingrid Biesheuvel (Amsterdam, 2001). 
with multiple prose adaptations in later centuries, ${ }^{15}$ as well as the compilation of many stories about Alexander the Great in the Alexanders geesten by Jacob van Maerlant. ${ }^{16}$ The similarly rich tradition of epic poetry on Charlemagne was preserved mainly in fragments. Medieval Dutch texts include adaptations of such works as La Chanson de Roland (Roelantslied), ${ }^{17}$ Renaut de Montauban (Renout van Montelbaen), mainly known from a prose adaptation, and De historie vanden vier Heemskinderen (The story of the four children of Aymon), ${ }^{18}$ as well as Ogier van Denemerken. ${ }^{19}$

III

KAREL ENDE ELEGAST

The Brabant epos from the thirteenth century, Karel ende Elegast, ${ }^{20}$ forms part of the tradition of chivalric literature related to Charlemagne. Although no earlier texts relating this exact episode from the life of Charles are preserved, the prologue tells us that everyone knows the tale. It was most probably popular in the oral tradition, and probably not only in the Low Countries.

The story is as follows: Charles is told by an angel to leave his castle and go stealing. On his way he meets the exiled Elegast. They break into the castle of Eggeric, the husband of Charles's sister, in Eggermonde, which is most probably Château d'Aigremont in present-day Belgium. Elegast discovers that a conspiracy against the emperor has been planned. The traitors are unmasked the next day, and after a fight against Eggeric, Elegast is reinstated and gets the hand of Eggeric's widow.

Although the author of the Dutch epic pointed out in the first lines of his text the trustworthiness of the story: 'Fraeye historie ende al waer / Mach ic u tellen' (A genuine and real story, I shall

${ }^{15}$ One of the prose texts, in a unique print from 1646 (Floris ende Blancefleur Een schone historie van Floris en Blanchefleur), is located in the library of the University of Wrocław (Oddział Starych Druków/Old Prints Department, ref. no. 432290).

${ }^{16}$ München, Bayerische Staatsbibliothek Cod. germ. 41, Jacob van Maerlant, Alexanders geesten, ed. Johannes Franck (Groningen, 1882).

${ }^{17}$ Hans van Dijk (ed.), Het Roelantslied (Utrecht, 1981).

${ }^{18}$ Irene Spijker (ed.), De historie vanden vier heemskinderen (Amsterdam, 2005).

19 The remarkable edition has been published in an online journal for Dutch Studies Neerlandistiek (previously Neder-L): Armand Berteloot, Ogier van Denemerken (2012-14).

${ }^{20}$ Geert Claassens, Karel ende Elegast (Amsterdam, 2002). 
tell you), ${ }^{21}$ this doesn't necessarily mean that a distinction between historia and fabula is being made. The words 'fraeye' and 'waer' could be understood as a reference to the distinction known in the classic rhetoric, whereby fabula is neither true nor possible. ${ }^{22}$ This would indicate that Karel ende Elegast is an account of historical events that happened in the past, according to the classical definition of historia. ${ }^{23}$ More likely it is just a rhetorical instrument aimed at attracting the audience. The word 'historie' is not always used for factual texts, but also sometimes for a fictional tale. ${ }^{24}$

The earliest complete text is an incunable from Delft. It was printed by Jacob Jacobsz van der Meer or Christiaen Snellaert, somewhere between 1486 and 1488. It is a very short epic poem of approximately 1400 verses. The earlier manuscripts (the contents of which are consistent with that of the later versions) have remained intact only in fragments, with the earliest dating from the second half of the fourteenth century. ${ }^{25}$ Most modern editions are thus based on the first printed version of the full text. ${ }^{26}$ The origin of the story is not certain, although a similar plot is incorporated into two Scandinavian works (Karl Magnus' Krønike and its Norse original Karlamagnús Saga), ${ }^{27}$ and the Chronica Alberici Monachi Trium Fontium mentions a song about a king, most probably Charlemagne, who went out stealing in the forest. ${ }^{28}$

${ }^{21}$ All citations of the Middle Dutch text are from Geert Claassens, Karel ende Elegast (Amsterdam, 2002), English translations by the author.

22 "Fabula est quae neque veras neque verisimiles continet res", Harry Caplan, Ad C. Herennium de ratione dicendi (Rhetorica ad Herennium) (London, 1954), 22.

23 "Historia est gesta res, sed ab aetatis nostrae memoria remota"; ibidem, 24.

${ }^{24}$ The various interpretations of the word 'historie' have been mentioned in the dictionary of Medieval Dutch (Middelnederlandsch Woordenboek 1250-1550 online). Céserine Abbenes has pointed out that the Dutch author may have played a literary genre game by using the description of historia and applying it to a fabula; see Céserine Abbenes, "Fraye historie ende al waer" Over fictie en werkelijkheid in Karel ende Elegast', Voortgang, 21 (2002), 253-73.

${ }^{25}$ The fragments in the Hague Royal Library (131 D 5) were written around 1375.

${ }^{26}$ For information about all copies known at that time, with a diplomatic edition, see Antonius M. Duinhoven (ed.), Karel ende Elegast. Diplomatische uitgave van de Middelnederlandse teksten en de tekst uit de Karlmeinet-compilatie (Zwolle, 1969).

${ }^{27}$ See de Ruiter, 'Karl Magnus' Krønike, Karlamagnús Saga, and Karel ende Elegast', 96-102.

${ }^{28}$ Albericus is most probably not referring to the Middle Dutch text but to another tale, probably an Old French text; see Antonius M. Duinhoven (ed.), Karel ende Elegast (The Hague, 1982), 25. 
Still, researchers such as Duinhoven or Claassens have not been able to determine with high probability whether the source was a French chanson de geste. Owing to the lack of certainty regarding the source of the Medieval Dutch Karel ende Elegast, the analysis of the male characters and their chivalric features shall be based on the text of the Delft print.

\section{IV \\ KAREL - THE MONARCH}

Karel (Charlemagne) ${ }^{29}$ is the main character of the story; there's no doubt about this. The first information we learn about him is that he is a mighty emperor. An angel comes to him and commands him to go out stealing, otherwise he would lose his throne and life. He's to take his spear, shield, and weapon and go out on his horse. He can't understand why he should go stealing as there's no other person on earth that's as rich as he is and he possesses the greatest (and largest) state, of which he is king. Whilst considering whether to follow the command or not, he utters a peculiar statement which unfolds his own appreciation of his status. He'd be willing to give everything away that he received from God, with the exception of his knightly armour:

Nochtan haddic liever vele,

Dat mi God name ghemeene

Dat ic van Hem houde te leene,

Beyde borch ende lant,

Sonder mijns ridders ghewant,

Ende ic mi moeste gheneeren

Mitten schilde ende metten speere

(Karel ende Elegast, 11. 103-9) ${ }^{30}$

This fragment can be read as a sign of the knightly culture. Karel can give away everything but the symbols of knighthood, which are the most important for him. One can argue though that the reason why

${ }^{29}$ As the story of the medieval text is analysed (not a historiographical account), the names given in the Dutch text shall be used here and not the historical counterparts.

30 "Yet I would prefer God to take away from me what I have received from Him, both castles and land, but not my knightly armour, so I could support myself with shield and spear". 
he wants to keep the armour above anything else is more pragmatic than idealistic. With a sword in his hand and armed with a shield, he could make sure his existence is secured and that he wouldn't have to beg for food.

As he leaves the castle, he's wearing his most precious clothes and armour, as it was always lying prepared by the side of his bed, a symbol of his majesty. The splendour of a great ruler has to be embodied in his physical appearance. He then reaches the stable unnoticed and gets on his horse. Entering the dark night he prays to God and subordinates himself completely to His will. From this moment on he's often referred to as 'die edel man' (the noble man), as if to emphasise that he belongs to aristocracy, but also as a sign of his concealed identity.

Once in the forest the first change in Karel's personality takes place. He realizes that thieves jeopardize their own livelihood, and in his mind he promises to never sentence anyone to death without good reason. He feels pity, especially for Elegast, from whom he took away his goods, but also for the knights who serve Elegast and who had been deprived of their possessions only because of the fact that they had served their lord. The moment Karel gets into the forest causes a radical change in his view. As a king he's mighty, powerful, and punishes those who do not follow the rules. Crossing the border between his castle and the surrounding wild nature is shown as a border between two different natures of the king. His remorse takes over, and he finds himself guilty of depriving people who had been loyal to him, and this even before meeting Elegast in person. This banished knight is the very one whose company Karel wishes to have that night, and his prayer is fulfilled.

Elegast gives a detailed description of Karel when they meet in the forest. He thinks Karel has lost his way because he doesn't seem to be poor. His armour and saddle are of the greatest value, decorated with gemstones and gold, something Elegast has not seen since his exile, and his horse belongs to the strongest available. Karel does not wish to reveal his identity, and thus chooses to fight the strange knight instead of talking to him, explaining that he's not supposed to be forced to say his name. When he wins the fight and realizes that the black knight is the one he asked God to bring to him, Karel adopts the identity of a thief, pretending his name is Adelbrecht. But he's not a Robin Hood kind of thief. He claims not to care about from 
whom he steals and he knows no remorse. The new identity adopted by Karel gives him the opportunity to express criticism of the feudal system, where the emperor has too much power. He calumniates the emperor (himself!) by saying that the goods in his castle are mostly stolen or taken unfairly.

His disguise is not successful for long. Arriving at the castle of Eggeric he prepares for the burglary. Unlike an experienced thief - as he tries to pretend to be - he finds a plough on the field and takes its coulter as a burglary tool. Elegast mocks Adelbrecht by the wall of Eggeric's castle for trying to use his tool for making a passage. His skills are lacking too, and although he is strong he has difficulties in digging a hole in the wall. His ineptness is later demonstrated by Elegast, who unnoticed steals the magic herbs from the mouth of Adelbrecht. A real thief would not let this happen.

Although Karel goes into the forest and starts his robbery adventure with Elegast, he remains a rather passive actor in their venture. It is not he who goes into the castle, nor he who takes any action to steal the goods. When he hears about the conspiracy against his life, he does not show rage, but rather contemplates the words of Elegast and looks for another proof of his loyalty.

The same applies in some way to the status of the monarch. Many times in the text Karel promises (to himself) that he'll compensate for his own wrongful actions towards Elegast as soon as he's back in his position as king. In his disguise as Adelbrecht, he also gives his loyal vassal advice to tell the king about the conspiracy, as he would be rewarded for this information. And when the moment comes, his pardon is granted: ${ }^{31}$

Ende ontboot hem herde houde

Ende vergaf hem alle misdaet.

(Karel ende Elegast, 11. 1151-2) (32 $^{32}$

${ }^{31}$ For many years a different punctuation has been used in editions and was determining translations, adaptations and interpretations, namely "Ende ontboot hem herde houde / Ende vergaf hem alle misdate / In dien dat hi den camp bestaet" [And sent for him and forgave all his crimes if he could win the fight]; see Duinhoven (ed.), Karel ende Elegast. Diplomatische uitgave. This new approach by Claassens is more consistent but changes the emperor's position not subjecting his decisions to higher forces (God).

32 "And sent quickly for him and forgave all his crimes". 
But even though Elegast is pardoned, and Karel knows that the story of Eggeric's intrigue is true, he lets the two fight a judiciallysanctioned duel in order to prove who was right. This decision can be understood according to two systems. On the one hand, God is the highest lord in the feudal system and only He can give the final judgement. By letting the two fight, Karel shows his loyalty to God. On the other hand, by letting Elegast fight a duel with another mighty knight, the emperor shows recognition of his abilities and follows a chivalric code of conduct.

\section{$\mathrm{V}$ \\ ELEGAST - THE OUTLAW}

Elegast is mentioned for the first time by Karel himself when he enters the forest. He remembers that he had banished him for a small offense ('om cleyne sake'). Later in the text Elegast states that he has lost his land and properties because of misfortune. He calls the emperor a righteous ruler anyway. Thus, before he appears we learn that the king sees him as a good person. This notion recurs throughout the text, when Karel repeatedly articulates his appreciation for the way Elegast was handling his misfortunes while remaining a faithful vassal. Although he was punished by the king and earns his living as a thief, he never steals from the poor who work hard, or from pilgrims or merchants, robbing only the rich clergy. When he appears however, not yet identified as Elegast, a very detailed description of him follows:

Met wapenen swart als colen.

Swart was helm ende schilt

Die hi aenden hals hilt;

Sinen halsberch mochtmen loven;

Swart was den wapenroc daer boven;

Swart was dors daer hi op sat;

Alsen die coninc ghemoeten soude,

Segende hi hem en was in vare

Ende waende dat die duvel ware,

Om dat hi was so swart al.

(Karel ende Elegast, 11. 276-87) ${ }^{33}$

${ }^{33}$ With armour black as coal. Black was his helmet and the shield he was holding; his mailcoat was to be praised; black was the surcoat on top of it; black was the 
This description directly follows the very positive assessment of Elegast by Karel. These two portrayals seem to depict two extremely different persons. The characterisation of him by Karel shows a good knight responsible for his vassals and, aside from a small fault, loyal to the courtly values; whereas the description of his physical appearance gives a picture so negative that even the mighty emperor feels fear. Until the moment his identity is revealed, Elegast is called 'the black' ('die swarte') in the text.

During the duel with Karel, Elegast fights well, but breaking his sword on Karel's helmet is a great loss for him.

... ic heb mijn swaert verloren.

En coeser gheen have voren,

Ende ict weder hadde gheheel.

(Karel ende Elegast, 11. 533-5) ${ }^{34}$

Just as was the case with Karel, so too the knight's armour and weapons are of great importance to Elegast. Even greater, as besides the symbolic meaning of his sword it is this that helps him look after his people and provide them with food.

His loyalty to the emperor is expressed the moment Adelbrecht (Karel in disguise of the thief) suggests stealing from the king's (i.e. his own) castle. The fierce reaction of Elegast confirms the exceptional bond between him and his (formal) overlord. His exile is not a sufficient reason for Elegast to cause any damage to the property of the king. Showing any kind of disrespect towards the king would imply his own disgrace, especially in the religious sense. ${ }^{35}$ Later in the text, after learning Eggeric's plans to kill Karel, the word grief ('rouwe') is used twice in a row to describe Elegast's reaction to this news. His action (he wants to decapitate the unfaithful knight) is a sign of rage, but his words show mainly sorrow, which is again a sign of his almost devotional loyalty to the king. The same is repeated in the

horse on which he sat; ... When the king saw him, he made the sign of the cross and was scared and thought he was the devil, because he was completely black.

${ }^{34}$ I've lost my sword. And I would choose no other possession than having it back in one piece.

${ }^{35}$ See Karel ende Elegast, 11. 625-6: "Dade ic hem anders dan eere / Ic mochs mi scamen voor Gode" (If I'd give him anything but respect, I would be ashamed before God). 
last scenes. When the heralds of Karel fetch Elegast, he expresses his joy saying there would be no greater good than to fight for the sake of the king's honour. Karel appreciates the devotion of his vassal and promises to give him his own sister in the event he vanquishes Eggeric in the duel.

When finally arriving at the castle of Eggeric, Elegast appears to have practised sorcery, which was harmless and reasonable ("minlic ende mate") - he was not a practitioner of black magic. He uses his powers to acquire information from animals and later, in the chambers of Eggeric, to make him and his wife fall asleep when he needs to leave the castle unnoticed.

After having brought the stolen goods from the castle, Elegast informs Karel that he needs to go back for the most precious possession - the saddle of Eggeric, which is the most beautiful that anybody has ever seen. The saddle is decorated with hundreds of golden bells which ring when the knight rides his horse. This seems to be the most important booty for Elegast, as he says he would rather be hanged than not try to steal it from Eggeric's bedroom. In this passage an inconsistency with the previous characterization of Elegast can be noted. Although he's been portrayed as an experienced thief, he makes an unreasonable mistake. All the bells start to ring (as he described earlier to Karel is always the case when the saddle is used) and Eggeric wakes up.

Elegast is thus an outlaw, but remains a knight and a vassal. He follows the feudal rules and the chivalric code of conduct, but some of his features, such as the magic he performs, give the character some extra relief. He is not just a figure representing a certain role, but a complex personality who makes mistakes (like the mischief for which he was banned, or the stealing of the saddle with the ringing bells). Unlike Karel, he doesn't change throughout the story and sticks to his values at all times.

\section{VI \\ EGGERIC - THE TRAITOR}

The first mention of Eggeric is in verse 648, when Elegast suggests stealing from his castle in Eggermonde instead of the emperor's castle. The first lines spoken by Elegast give a very negative impression of the character of Eggeric. Although married to the sister of the king 
and receiving from him both land and property, he earned no respect from the knight Elegast. Eggeric is a traitor to his kin and to his king. At first Elegast offers no explanation on what his judgement is based. Karel, however, does not correct him in any way.

Eggeric has a great castle with the best and the most beautiful fortifications and is married to the sister of Karel, which makes him part of the emperor's family. The passages in the text related to him are very short, and no objective description is included in the narrative. But we learn that he supports a plan to assassinate Karel and was chosen (from among a group who he mentions to his wife but who are not mentioned by name in the text) to carry out the murder. It seems that he is not regarding this as a simple and a straightforward task, as he hasn't been sleeping well or eating for several days. But when his wife reacts fiercely against this plan, he immediately hits her and her nose starts bleeding.

When at the end of the story Elegast enters the castle of Karel, he greets everyone besides Eggeric, saying he's not to be greeted as he has voluntarily declared to kill the king. Being disloyal to the king, Eggeric has broken the rules of the chivalric code of conduct. He also violated the rules by slapping his wife. Elegast, who witnessed this incident, caught some drops of her blood to be able to prove his misbehaviour towards the sister of the emperor. Eggeric thus breaks all the rules of proper conduct towards both his lord and his wife.

Many times the text refers to the beauty of certain of Eggeric's possessions. His castle is the most beautiful and best there is ("de scoonste ... ende die beste"), and the saddle with golden bells is the most beautiful any man has ever seen ("Die scoonste die noyt man sach"). It is difficult to assess whether the repeated praise of his goods can be seen as a sign of his attachment to only material values as opposed to the ethos of a loyal knight. A more probable interpretation is that these statements are meant to emphasize the special position of Eggeric, who is not a regular subject of the king but a powerful and wealthy lord in his own right.

\section{VII \\ CHIVALRIC RULES}

Both Karel and Elegast follow the chivalric code. There are some moments however when they act otherwise. One of the first of these 
moments is their encounter in the forest. They see each other, each assessing his counterpart, and pass by each other without even greeting one another. And it is Elegast who expresses astonishment with this incident. He interprets the silence of Karel as a bad sign, thinking that he might want to hurt him or his vassals. He sees no other explanation for the presence of a lonely knight in the woods than the pursuit of the outcast. Strangely enough another possibility, that of another banished knight, is not even mentioned.

More often however they do act according to the chivalric code. A moment of knightly conduct by the rules comes not much later, during the duel between the two. They both seem to have substantially equal chances, but at the end Elegast's sword breaks on the helmet of Karel. The empty-handed knight thinks his life is forfeited, but the king knows it is a disgrace to strike someone standing vulnerable and defenceless in front of him. The rules of fair play were part of an unwritten code of conduct. ${ }^{36}$ The same rule is applied in one of the last scenes. The king's brother-in-law falls from his horse during the duel with Elegast. Elegast asks him to get back into the saddle and fight as a knight, which a clear sign of respect for the chivalric rule of a fair fight. It is more honourable to die in a fair duel than to win by using a momentary advantage instead of one's own strength and capabilities.

A certain rule of conduct is also applied to the thieves' customs. When Elegast and Adelbrecht (Karel) arrive at the castle of Eggeric, Elegast offers Adelbrecht to go into the castle on his own, which would mean that the credits from the robbery would fall on him. Theft is a crime, but even in such unworthy circumstances the two maintain their belief in rightfulness. But Elegast is mainly an outlaw, a knight banned to the forest due to misfortune, a character widespread in the European literature of the High and Late Middle Ages. ${ }^{37}$

\section{VIII}

RELIGION, CHURCH, AND MAGIC

An interesting feature of Karel appears in his monologue upon his arrival to the forest. As he praises Elegast for his choice to not steal

${ }^{36}$ Richard W. Kaeuper, Medieval Chivalry (Cambridge, 2016), 10-11.

${ }^{37}$ See the publications in the Routledge Series Outlaws in Literature, History, and Culture, edited by Lesley A. Coote and Alexander L. Kaufman (2016-2019). 
from the poor, at the same time Karel is admiring him for stealing from a wide range of wealthy clergymen: bishops, priests, monks, and deacons. Thus, although religion plays an important role in his life (he carries out the difficult tasks given to him by God, prays to Him often asking for a help, and finally trusts His justice in the outcome of the final fight between Elegast and Eggeric), he's nonetheless critical of the clergy. He expects the other knight, who he considers to be faithful, to believe in the power of God too. When Elegast tells him at Eggeric's castle that the animals told him of the presence of the king in the surroundings of the fortress, he protests strongly against this belief in the rightfulness of the animal world and accuses Elegast of losing his true faith (in God). The merger of knighthood and religion is typical for the figure of rulers in the courtly literature and derives from Christian elements in the late antiquity. ${ }^{38}$

There's also a strange mix of Christian beliefs and magic. Although Elegast is believed to have the power of harmless magic (which he uses to understand the language of animals or make people fall asleep), the text shows inconsistencies in the way he influences his surroundings. When in the chambers of Eggeric and his wife he needs to put them to sleep, and we read:

Doe seyde Elegast een ghebede

Daer hi mede slapen dede

Eggeric ende die vrouwe

(Karel ende Elegast, 11. 922-4) $)^{39}$

This part resembles an earlier episode when Karel is leaving his castle, where it is God Himself then who makes all the other people in the castle fall asleep. Elegast is using magic, but using a prayer to perform it.

The text portrays the characters differently in regard to their beliefs. As both Karel and Elegast, the positive figures, use prayers in many moments to either ask for a kind fate or trust their actions to God, Eggeric does not pray even before the final fight. After a long prayer by Elegast, the text states briefly:

${ }^{38}$ Joachim Bumke, Höfische Kultur. Literatur und Gesellschaft im hohen Mittelalter (München, 1986), 382-4.

${ }^{39}$ Then Elegast said a prayer that made them both, Eggeric and his wife, fall asleep. 
Hi en seide noch en dede

Te Gode waert gheene bede

(Karel ende Elegast, 11. 1320-1) ${ }^{40}$

This pejorative statement confirms that Eggeric is the bad character in the story.

\section{IX \\ CONCLUSIONS}

In December 1165, some 350 years after the death of Charlemagne, the most important European rulers gathered in Aachen, the place of death and burial of the great Emperor, to declare him a saint. The politically-motivated canonization by Antipope Paschal III took place under rather ambiguous circumstances and is not considered valid. ${ }^{41}$ An echo of the event may be seen in Karel ende Elegast, where the central position of Charlemagne distinguishes the text from other chivalric poems where this great King did not play an active role in the plot. His religious importance is emphasized at the beginning when he is chosen to take part in a miracle. Some may think this is almost a hagiographical text - the main character, a saint (Karel) confirms that he can count on the protection of God and is a mediator between the sinner (Elegast) and the Lord. An evil character (Eggeric) threatens him, but he is victorious thanks to the support of God. But the strong chivalric character of the epos makes it possible to see it as an example of several knight figures. And although the idea of a homogenous 'chivalric code of conduct' that applied to all knights in Europe is rather a modern one and based on a combination of a number of ideals presented in several medieval texts, Karel ende Elegast incorporates it in a very subtle manner. Eggeric is an explicitly bad character with no respect for the rules, but also with no esteem from others. Elegast exemplifies a fair knight and a loyal vassal; but he's also a more complex figure living in the woods and using magic. He is at the same time an embodiment of the outlawed knight. Finally, Karel is not only the fair knight but mainly the rightful ruler appointed by

${ }^{40}$ He didn't speak and said no prayer to God.

${ }^{41}$ See Jace Stuckey, 'The Twelfth-Century Vita Karoli and the Making of a Royal Saint', in William J. Purkis and Matthew Gabriele (eds.), The Charlemagne Legend in Medieval Latin Texts (Suffolk and Rochester, 2016), 39-43. 
God, who learns through his own failures and corrects his previous mistakes. As such he represents a critic of the system he himself rules. It is a story of three knights, but also of three very different characters with diverse approaches towards the chivalric code of conduct.

proofreading James Hartzell

\section{SELECTED BIBLIOGRAPHY}

Abbenes Céserine, 'Fraye historie ende al waer. Over fictie en werkelijkheid in Karel ende Elegast', Voortgang, 21 (2002), 253-73.

Besamusca Bart and Tigelaar Jaap (eds.), Karolus Rex. Studies over de middeleeuwse verhaaltraditie rond Karel de Grote (Hilversum, 2006).

Claassens Geert, Karel ende Elegast (Amsterdam, 2002).

Duinhoven Antonius M. (ed.), Karel ende Elegast. Diplomatische uitgave van de Middelnederlandse teksten en de tekst uit de Karlmeinet-compilatie (Zwolle, 1969).

Koch Jerzy and Oczko Piotr (eds.), Widzę rzeki szerokie...: z dziejów dawnej literatury niderlandzkiej (Poznań, 2018).

Oostrom Frits van, Stemmen op schrift: geschiedenis van de Nederlandse literatuur vanaf het begin tot 1300 (Amsterdam, 2006).

Ruiter Jacqueline de, 'Karl Magnus' Krønike, Karlamagnús Saga, and Karel ende Elegast: Genre, Form, Function', Enk S. Kooper (ed.), The Medieval Chronicle: Proceedings of the 1st International Conference on the Medieval Chronicle (Amsterdam, 1999), 96-102 .

Ruiter Jacqueline de, 'Traces of Orality in Charlemagne's Thieving Adventure', Olifant, xxv, 1-2 (2006), 175.

Stuckey Jace, 'The Twelfth-Century Vita Karoli and the Making of a Royal Saint', in William J. Purkis and Matthew Gabriele (eds.), The Charlemagne Legend in Medieval Latin Texts (Suffolk and Rochester, 2016), 33-58.

Tilvis Pentti, 'Mittelniederländisches im Prosa-Lancelot I', Neuphilologische Mitteilungen, lii, 4 (1951), 195-205.

Małgorzata Dowlaszewicz - medieval Dutch literature; assistant professor at the Erasmus Chair of Dutch Philology, University of Wrocław;

e-mail: malgorzata.dowlaszewicz@uwr.edu.pl 